\title{
KARAKTERISTIK, MOTIVASI DAN PERSEPSI WISATAWAN MANCANEGARA KE DESA WISATA TRUNYAN, KINTAMANI
}

\author{
I Putu Angga Pratama ${ }^{1}$, LGK. Dewi ${ }^{2}$, NMO. Karini ${ }^{3}$ \\ Email: anggapratama130597@gmail.com ${ }^{1}$, leli_ipw@unud.ac.id ${ }^{2}$, karini_ipw@unud.ac.id ${ }^{3}$ \\ ${ }^{1,2,3}$ Program Studi Industri Perjalanan Wisata, Fakultas Pariwisata, Universitas Udayana
}

\begin{abstract}
Tourists who travel to a tourism village certainly have different characteristics, motivations, and perceptions. These three things are very important to be identified, because they can become a reference material for the local community and the government related to selfimprovements, facilities-improvements, infrastructure, management, and services in Trunyan Tourism Village that can affect the tourist and the returning of them, and are able to provide excellent service in accordance with the tourists expectations. The purpose of this study is to identify the characteristics, motivations, and perceptions of the foreign tourists who travel to Trunyan Tourism Village. Data collection techniques used in this research are observation, unstructured interviews, questionnaires, literature study, and documentation. Accidental sampling techniques used to take a sample of 100 people. Data analysis technique used in this study is descriptive qualitative data analysis technique. The results show that the most foreign tourists who travel to Trunyan Tourism Village are 33\% from United States, $40 \%$ with an age range of 15-30 years old, 55\% males, $29 \%$ working as employees, and $39 \%$ of master-educated. A total of $61 \%$ tourist state that the purpose of the travel is to travel/recreation, $65 \%$ state that the arrangement of the travel is arranged by the travel agency, $100 \%$ are first timers, $49 \%$ receive the information about Trunyan Tourism Village through the travel agency, $54 \%$ spend $\$ 39-\$ 54$, and $85 \%$ are accompanied by friends/family. The motivation that push foreign tourists to travel to Trunyan Tourism Village is novelty and knowledge seeking of 4.10, while the motivation that pull foreign tourists to travel to Trunyan Tourism Village is safety, cleanliness, and variety attraction of 3.71. The foreign tourists who travel to Trunyan Tourism Village have good perceptions/agree with the average total score of 3,60.
\end{abstract}

Abstrak: Wisatawan yang berwisata ke desa wisata tentu memiliki karakteristik, motivasi, dan persepsi yang berbeda. Ketiga hal ini sangat penting untuk diidentifikasi, karena dapat menjadi bahan acuan bagi masyarakat lokal dan pemerintah terkait untuk berbenah diri, meningkatkan sarana, prasarana, manajemen, dan layanan di Desa Wisata Trunyan yang dapat mempengaruhi wisatawan dan kembalinya mereka, serta mampu memberikan pelayanan prima sesuai dengan harapan wisatawan. Tujuan studi ini adalah untuk mengidentifikasi karakteristik, motivasi, dan persepsi wisatawan mancanegara yang berwisata ke Desa Wisata Trunyan. Teknik pengumpulan data yang digunakan dalam studi ini adalah observasi, wawancara tidak terstruktur, kuesioner, studi kepustakaan, dan dokumentasi. Teknik accidental sampling digunakan untuk mengambil 100 sampel. Teknik analisis data yang digunakan dalam studi ini adalah teknik analisis data deskriptif kualitatif. Hasil penelitian menunjukkan bahwa sebagian besar wisatawan mancanegara yang berwisata ke Desa Wisata Trunyan adalah 33\% wisatawan dari Amerika Serikat, 40\% wisatawan dengan rentang usia 15-30 tahun, 55\% wisatawan pria, 29\% wisatawan yang bekerja sebagai karyawan, dan 39\% wisatawan yang berpendidikan master. Sebanyak $61 \%$ wisatawan menyatakan bahwa tujuan perjalanannya adalah untuk berwisata/rekreasi, 65\% wisatawan menyatakan bahwa pengaturan perjalanannya diatur oleh biro perjalanan wisata, $100 \%$ wisatawan first timer, $49 \%$ wisatawan memperoleh informasi tentang Desa Wisata Trunyan melalui biro perjalanan wisata, 54\% wisatawan menghabiskan dana sekitar $\$ 39-\$ 54$, dan $85 \%$ wisatawan berwisata bersama teman/keluarga. Motivasi yang mendorong wisatawan mancanegara berwisata ke Desa Wisata Trunyan adalah mencari kebaruan dan pengetahuan sebesar 4,10, sedangkan motivasi yang menarik wisatawan mancanegara berwisata ke Desa Wisata Trunyan adalah keamanan, kebersihan, dan variasi atraksi wisata sebesar 3,71. Wisatawan mancanegara yang berwisata ke Desa Wisata Trunyan memiliki persepsi yang baik/setuju dengan total skor rata-rata sebesar 3,60.

Keywords: characteristic, motivation, perception, foreign tourist, trunyan village. 


\section{PENDAHULUAN}

Pariwisata mempunyai peran yang sangat penting dalam pembangunan Indonesia khususnya sebagai penghasil devisa negara disamping sektor migas. Pada tahun 2009, pariwisata menempati urutan ketiga dalam hal penghasil devisa, setelah komoditi minyak dan gas bumi serta minyak kelapa sawit. Tujuan pengembangan pariwisata di Indonesia terlihat dengan jelas dalam Instruksi Presiden Republik Indonesia No. 9 tahun 1969, khususnya BAB II pasal 3 yang menyebutkan "usaha-usaha pengembangan pariwisata di Indonesia bersifat suatu pengembangan (industri pariwisata) dan merupakan bagian dari usaha pengembangan dan pembangunan serta kesejahteraan masyarakat dan negara“.

Negara Kesatuan Republik Indonesia merupakan negara kepulauan terbesar di dunia yang terdiri dari 17.504 pulau besar maupun pulau kecil dari Sabang hingga Merauke yang memiliki bentang alam yang sangat indah, keanekaragaman flora dan fauna, berbagai macam seni, tradisi, adat istiadat maupun budaya, selain itu masyarakat Indonesia juga terkenal dengan keramahannya di mata dunia. Atas dasar pertimbangan tersebut pemerintah Indonesia berusaha untuk mengembangkan sektor pariwisata yang pengembangannya didasarkan pada potensi masing-masing daerah. Oleh sebab itu, pemerintah Indonesia melalui Kementerian Pariwisata menargetkan 20 juta wisatawan mancanegara berkunjung ke Indonesia pada tahun 2019. Kunjungan wisatawan mancanegara ke Indonesia (JanuariAgustus 2018) mencapai 10,58 juta kunjungan atau naik $12,30 \%$ dibandingkan dengan jumlah kunjungan wisatawan mancanegara periode yang sama pada tahun 2017 yang berjumlah 9,42 juta kunjungan (Badan Pusat Statistik Indonesia, 2018).

Bali sebagai salah satu destinasi pariwisata nasional maupun internasional telah memberikan kontribusi terhadap devisa negara. Pulau Bali dalam benak wisatawan memiliki banyak julukan seperti Pulau Dewata, Pulau Surga, Pulau Seribu Pura dan masih banyak julukan lainnya serta pulau ini sangat kaya akan keindahan alam, budaya dan adat istiadat. Masyarakat Bali dengan budaya agrarisnya yang kental dengan kehidupan sosial yang harmoni karena hubungan serasi antara manusia dengan Tuhan, sesamanya, dan alam yang disebut Tri Hita Karana. Industri pariwisata di Bali selain mendahulukan nilainilai kapitalis juga memberikan nuansa sentuhan-sentuhan budaya di dalam setiap atraksinya, sehingga Bali dapat menjadi salah satu destinasi pariwisata favorit yang layak dikunjungi oleh siapapun yang ingin melakukan perjalanan wisata.

Tingkat kunjungan wisatawan mancanegara ke Bali mengalami peningkatan dengan rata-rata pertumbuhan sebesar 10,308. Meningkatnya jumlah kunjungan tersebut dikarenakan perkembangan pariwisata Bali yang semakin maju yang tercermin dengan tersedianya berbagai macam fasilitas pendukung pariwisata, seperti akomodasi, transportasi, rekreasi, teknologi informasi dan komunikasi, serta adanya atraksi wisata baru yang mampu menarik kunjungan wisatawan yang lebih banyak dan lain sebagainya. Kemajuan dalam berbagai bidang tersebut menjadi salah satu bentuk dukungan dan perhatian masyarakat, pemerintah beserta pihak terkait maupun swasta dalam pengembangan kepariwisataan yang ada di Bali. Dari sekian banyaknya wisatawan yang berwisata ke Bali, terdapat berbagai macam daya tarik wisata yang menarik dikunjungi wisatawan untuk menikmati liburannya.

Kabupaten Bangli merupakan salah satu kabupaten dari 8 kabupaten yang ada di Bali yang mengandalkan sektor pariwisata sebagai sektor andalan selain sektor pertanian dan industri-industri lainnya. Pariwisata terbukti mampu menggalakkan kegiatan ekonomi dan sektor lain sehingga dapat meningkatkan lapangan kerja, kesempatan berusaha, pendapatan masyarakat serta pendapatan daerah kabupaten Bangli. Bertolak dari hal tersebut, kabupaten Bangli sendiri berupaya menata objek wisata yang ada serta mengembangkan objek lain yang belum maksimal tergarap.

Selain menata fisik, pemerintah kabupaten Bangli berusaha mengembangkan sumber daya manusia atau para pelaku pariwisata itu sendiri dengan melakukan pelatihan maupun penyuluhan serta study banding ke daerah lain yang sudah lebih baik. Upaya-upaya ini diharapkan mampu meningkatkan kunjungan wisatawan ke kabupaten Bangli sehingga dapat meningkatkan kesejahteraan masyarakat 
Bangli dan juga pendapatan asli daerah kabupaten Bangli. Kabupaten ini merupakan satu-satunya dari 8 kabupaten di Bali yang tidak memiliki garis pantai, namun memiliki potensi pariwisata yang cukup besar. Event adat dan budaya di wilayah Bangli utara dan juga kawasan lainnya sangat unik dan tidak dapat ditemukan di tempat lainnya. Disamping itu, Bangli memiliki berbagai fakta unik lainnya yang tidak banyak diketahui orang yaitu memiliki desa dengan cara penguburan yang berbeda dari tradisi di Bali pada umumnya (Desa Wisata Trunyan), memiliki desa terbersih di dunia (Desa Wisata Penglipuran), memiliki Global Geopark pertama di Indonesia dan masih banyak lainnya (Dinas Pariwisata dan Kebudayaan Kabupaten Bangli, 2017).

Desa Wisata Trunyan merupakan salah satu Desa Bali Mula (Desa Bali Asli) yang dihuni oleh masyarakat Bali Aga (Bali Asli). Penduduk Desa Wisata Trunyan memiliki tradisi yang sangat berbeda dengan tradisi di Bali pada umumnya. Hal utama yang paling dikenal dan menarik wisatawan untuk berwisata adalah kuburan Desa Wisata Trunyan. Pada umumnya masyarakat di Bali melakukan pembakaran mayat yang dikenal dengan istilah upacara Ngaben. Namun, penduduk Desa Wisata Trunyan tidak melakukan upacara ini, melainkan mayat orang meninggal tersebut hanya dibaringkan di atas tanah, dikelilingi bambu berupa ancak, serta diletakkan di bawah pohon keramat yakni 'Taru Menyan' yang merupakan cikal bakal nama desa. Kata 'Taru' dan 'Menyan' kemudian membentuk nama desa menjadi Trunyan. Pohon ini diyakini oleh masyarakat mengeluarkan bau harum yang dapat menyerap bau-bau mayat yang diletakkan disekitarnya. Disamping itu, para wisatawan dapat mengunjungi Pura Ratu Gede Pancering Jagat dan menonton Tari Barong Brutuk yang dapat disaksikan pada Purnama Sasih Kapat yang umumnya jatuh pada bulan Oktober.

Desa Wisata Trunyan sempat sangat populer pada tahun 1970 hingga 1980-an. Namun lambat laun, Desa Wisata Trunyan mengalami krisis kunjungan wisatawan akibat diterpa isu-isu negatif. Oleh sebab itu, pengelolaan Desa Wisata Trunyan diharapkan lebih profesional yang akan berimplikasi pada tingkat kunjungan wisatawan di masa yang akan datang. Pertumbuhan kunjungan wisatawan mancanegara ke Desa Wisata
Trunyan dalam kurun waktu lima tahun terakhir yakni fluktuatif, bahkan menunjukkan penurunan. Tidak mudah untuk mempertahankan suatu daerah menjadi desa wisata yang selalu diminati oleh para wisatawan, perlu adanya komitmen dan kerjasama yang baik antara masyarakat sebagai aktor utama, pihak swasta sebagai perantara, dan pemerintah sebagai pihak pengambil kebijakan. Setiap wisatawan memiliki cerita positif maupun negatif setelah berwisata ke Desa Wisata Trunyan. Beberapa komentar negatif wisatawan untuk desa wisata tersebut kebanyakan muncul dari berbagai macam hal yang mereka alami selama berwisata di desa wisata ini, seperti kebersihan area sekitar desa wisata maupun kuburannya, sikap agresif masyarakat lokal dalam menjajakan barang dagangannya serta adanya lansia yang mengemis. Meskipun banyak rumor negatif yang beredar, tetapi selalu mengundang rasa penasaran wisatawan untuk berwisata. Walau terdapat wisatawan yang mengurungkan niatnya untuk berwisata ke desa wisata tersebut, tetapi adapula wisatawan yang mencari biro perjalanan wisata yang memiliki kredibilitas serta komentar positif dalam memandu wisatawan. Dengan menggunakan jasa ini, sedikit tidaknya akan mengurangi kecurangan ataupun permasalahan yang terjadi, dan meminimalkan ketidakpahaman wisatawan terhadap Desa Wisata Trunyan.

Wisatawan yang berwisata ke sebuah desa wisata memiliki karakteristik, motivasi, maupun persepsi yang berbeda, sehingga karakteristik dan motivasi wisatawan mancanegara sangat penting untuk diidentifikasi guna menentukan pelayanan maupun pengelolaan ke depannya, sebab keinginan ataupun kebutuhan wisatawan terkadang berhubungan dengan karakteristik serta motivasinya berwisata ke suatu desa wisata. Selain itu, persepsi wisatawan tersebut juga sangat penting untuk diidentifikasi, sebab dengan memahami persepsi wisatawan tersebut tentang desa wisata yang mereka kunjungi akan menjadi bahan acuan bagi masyarakat lokal dan pemerintah terkait untuk berbenah diri, meningkatkan sarana, prasarana pendukung aktivitas wisata, pengelolaan dan pelayanan di Desa Wisata Trunyan yang nantinya dapat mempengaruhi kunjungan kembali dan kunjungan wisatawan lainnya, mampu memberikan pelayanan prima yang 
sesuai dengan ekspektasi para wisatawan yang diharapkan nantinya akan berujung pada kepuasan yang mampu mendorong loyalitas para wisatawan pada desa wisata ini. Berlandaskan pertimbangan tersebut, peneliti ingin melakukan penelitian berjudul Karakteristik, Motivasi dan Persepsi Wisatawan Mancanegara yang Berwisata ke Desa Wisata Trunyan Kintamani.

\section{METODE PENELITIAN}

Studi ini dilaksanakan di Desa Wisata Trunyan, Kintamani. Variabel yang digunakan adalah variabel karakteristik yang dibagi menjadi dua sub variabel antara lain sub variabel Tourist Descriptor, meliputi SosioDemografis dan Geografis, serta sub variabel Trip Descriptor (Seaton \& Bennet, 1996). Variabel motivasi terdiri dari dua sub variabel yaitu sub variabel Push Factor, meliputi Novelty and Knowledge Seeking, Rest and Relaxation, Fulfilling Dream, Adventure and Exploration, dan Prestige. Serta sub variabel Pull Factor, meliputi Safety, Cleanliness, and Variety Attraction, Event and Activities, Affordable Price, dan Travel Arrangement (Yuan \& McDonald, 1990). Variabel persepsi terdiri atas lima sub variabel yaitu sub variabel Attraction, meliputi Keindahan Alam, Iklim dan Cuaca, Kebudayaan, dan Sejarah. Sub variabel Facility, meliputi Warung Tradisional, Area Parkir, dan Toilet. Sub variabel Infrastructure, meliputi Jaringan Komunikasi, dan Jalan. Sub variabel Transportation, meliputi Layanan Transportasi Lokal. Serta sub variabel Hospitality, meliputi Pemandu Lokal, dan Masyarakat Lokal (James. J. Spillane, 1994:63-72).

Pengumpulan data dalam studi ini melalui observasi, wawancara tidak terstruktur, kuesioner, studi kepustakaan, serta dokumentasi. Studi ini menggunakan kuesioner yang dibagikan kepada wisatawan mancanegara yang berwisata ke Desa Wisata Trunyan Kintamani dengan skala Likert sebagai media untuk mengidentifikasi motivasi dan persepsi wisatawan tersebut. Dalam mengambil dan menentukan sampel pada studi ini, maka digunakanlah teknik accidental sampling dan rumus Slovin, dimana sampel studi ini berjumlah 100 sampel, serta teknik analisis data yang digunakan adalah teknik analisis data deskriptif kualitatif.

\section{HASIL DAN PEMBAHASAN}

Desa Wisata Trunyan berjarak sekitar $70 \mathrm{~km}$ dari Kota Denpasar, yakni tepatnya di tepi Danau Batur atau di kaki barat Bukit Abang. Desa wisata ini dapat dicapai dengan dua akses yaitu melalui perjalanan darat menggunakan mobil/sepeda motor, namun aksesibilitasnya cukup berbahaya jika belum terbiasa dengan medan yang menanjak dan tikungan tajam. Akses selanjutnya melalui perjalanan air menggunakan perahu dari dermaga Desa Kedisan menyeberangi Danau Batur selama 30 menit. Kuburan Trunyan merupakan atraksi utama bagi wisatawan untuk berwisata ke Desa Wisata Trunyan.

\section{Karakteristik Wisatawan}

Karakteristik wisatawan mancanegara yang berwisata ke Desa Wisata Trunyan adalah sebagai berikut.

1. Didominasi oleh wisatawan mancanegara asal Amerika Serikat sebesar 33\%, karena adanya musim liburan di negara tersebut sehingga dapat berwisata khususnya ke Desa Wisata Trunyan.

2. Mayoritas responden pada studi ini adalah wisatawan mancanegara yang berumur antara 15-30 tahun sebesar 40\%, dimana rentang umur tersebut merupakan umur produktif dan sangat peka terhadap perkembangan teknologi informasi dan komunikasi khususnya media sosial, serta beberapa responden mendapat informasi tentang desa wisata ini melalui media sosial.

3. Wisatawan mancanegara yang berjenis kelamin laki-laki mendominasi kunjungan ke Desa Wisata Trunyan sebanyak 55\%. Hal ini terjadi karena umumnya laki-laki memiliki jiwa penjelajah yang lebih tinggi daripada perempuan.

4. Lebih banyak bekerja sebagai karyawan sejumlah 29\%, karena karyawan telah berpenghasilan tetap yang bisa digunakan untuk berwisata jika dibandingkan dengan pelajar/mahasiswa yang belum bekerja.

5. Kebanyakan responden memiliki tingkat pendidikan master sebanyak $39 \%$ yang menjadikan responden lebih kooperatif dalam memberikan jawaban pada lembar kuesioner yang diberikan kepadanya.

6. Berwisata/rekreasi merupakan mayoritas jawaban responden yakni $61 \%$, sebab desa wisata ini menyimpan daya tarik yang sangat khas yang tak dapat dijumpai pada desa wisata lain di Bali maupun dunia. 
7. Dalam pengorganisasian perjalanannya, kebanyakan responden menggunakan biro perjalanan wisata dengan total jawaban $65 \%$. Dengan menggunakan jasa ini akan memudahkan wisatawan untuk berwisata khususnya ke Desa Wisata Trunyan.

8. Seluruh responden merupakan first timer. Hal tersebut bisa disebabkan karena ketidaktahuan responden tentang eksistensi desa wisata ini dan bisa juga akibat kurangnya kegiatan promosi yang maksimal dan berkesinambungan.

9. Selain mengorganisasikan perjalanan, biro perjalanan wisata juga berperan penting dalam menyebarluaskan informasi tentang Desa Wisata Trunyan. Hal ini dapat terjadi karena setiap biro perjalanan wisata pasti memberikan jasa pemandu wisata kepada setiap konsumennya.

10. Mayoritas pengeluaran responden di Desa Wisata Trunyan berkisar $\$ 39-\$ 53$, dimana pengeluaran tersebut dikeluarkan untuk menyewa perahu penyeberangan menuju kuburan dan Desa Wisata Trunyan serta membeli keperluan pribadi responden.

11. Berdasarkan teman perjalanannya, mayoritas responden berwisata ke desa wisata ini bersama teman/keluarganya. Hal tersebut selaras dengan hasil observasi di lapangan, dimana kebanyakan responden berwisata bersama teman/keluarganya.

\section{Motivasi Wisatawan}

Motivasi wisatawan mancanegara yang berwisata ke Desa Wisata Trunyan dapat diklasifikasikan menjadi dua antara lain.

1. Faktor Pendorong (Push Factor)

Faktor dasar yang mendorong wisatawan mancanegara untuk berwisata ke Desa Wisata Trunyan terdiri dari lima indikator antara lain :

a. Novelty and Knowledge Seeking (Mencari Kebaruan dan Pengetahuan)

Indikator ini memperoleh total skor rata-rata sebesar 4,10 yang berarti para responden setuju untuk mencari kebaruan dan pengetahuan berwisata ke Desa Wisata Trunyan. Sebagian besar responden beralasan ingin mencari sesuatu yang khas dan berbeda, yang tidak banyak diketahui, dikunjungi maupun dilakukan oleh kebanyakan wisatawan, adapula yang ingin belajar tentang Bali yang sesungguhnya. b. Rest and Relaxation (Istirahat dan Relaksasi)

Indikator ini mendapat total skor ratarata sebanyak 4,02 yang masuk ke dalam kategori setuju. Salah satu responden menyatakan bahwa dia berwisata ke Bali karena bulan madu dan ingin menghabiskan waktu bersama istrinya. Disamping itu, dia dan sang istri sangat kagum dengan Bali khususnya budaya dan tradisi masyarakat Bali, mereka menemukan beberapa foto dan video mayat serta tengkorak misterius di media sosial yang tidak lain adalah mayat dan tengkorak di kuburan Trunyan, sehingga mereka memutuskan untuk berwisata ke desa wisata ini

c. Fulfilling Dream (Memenuhi Mimpi) Indikator tersebut mendapat total skor rata-rata 3,77 berarti responden setuju untuk memenuhi mimpi berwisata ke Desa Wisata Trunyan. Salah satu responden menyatakan banyak temannya yang berwisata ke Bali, namun mereka semua belum ada yang pernah berwisata ke Desa Wisata Trunyan. Itulah salah satu alasan yang mendorong dia berwisata bersama keluarganya ke Desa Wisata Trunyan.

d. Adventure and Exploration (Petualangan dan Eksplorasi)

Indikator petualangan dan eksplorasi Desa Wisata Trunyan memperoleh total skor rata-rata sebanyak 4,01 sehingga masuk ke dalam kategori setuju. Masa muda adalah masa dimana seseorang memiliki jiwa berpetualang dan jelajah yang membuat penasaran dan menarik menurut mereka. Begitu pula yang dilakukan oleh sebagian besar responden pada penelitian ini yang didominasi oleh usia 15-30 tahun yakni berpetualang serta menjelajahi berbagai atraksi wisata di Bali yang belum atau jarang dikunjungi oleh wisatawan termasuk Desa Wisata Trunyan.

e. Prestige (Gengsi)

Indikator gengsi memperoleh total skor rata-rata sebesar 3,98 berarti responden setuju berwisata ke Desa Wisata Trunyan karena gengsi. Beberapa responden menyatakan alasannya berwisata ke Desa Wisata Trunyan yaitu untuk menambah postingan di 
media sosial yang secara tidak langsung guna menunjukkan dan meningkatkan harga dirinya kepada khalayak umum. Disamping itu, sebagian besar responden sangat setuju untuk menceritakan segala hal yang dijumpai dan diperoleh selama berwisata di Desa Wisata Trunyan, serta suatu hari nanti mereka akan kembali lagi khususnya ke Desa Wisata Trunyan bersama teman/keluarganya.

Faktor pendorong wisatawan mancanegara berwisata ke Desa Wisata Trunyan mendapat total skor rata-rata sebesar 3,98 yang masuk dalam kategori setuju yang didapatkan dari hasil kalkulasi semua indikator diatas.

\section{Faktor Penarik (Pull Factor)}

Faktor dasar yang menarik wisatawan mancanegara untuk berwisata ke Desa Wisata Trunyan terdiri atas empat indikator, yaitu :

a. Safety, Cleanliness, and Variety Attraction (Keamanan, Kebersihan, dan Variasi Atraksi Wisata)

Indikator di atas mendapat total skor rata-rata sebesar 3,71 bermakna bahwa para responden setuju berwisata ke Desa Wisata Trunyan karena keamanan, kebersihan, dan variasi atraksi wisatanya. Responden berpendapat bahwa sekeliling Desa Wisata Trunyan sebenarnya sangat indah yang tidak bisa dijumpai di negaranya, namun sangat disayangkan untuk hal kebersihan dan fasilitas kurang terjaga dengan baik. Mereka berharap masyarakat setempat untuk membenahi dan meningkatkan hal yang paling penting menurut kebanyakan wisatawan yakni kebersihan daya tarik wisata yang mereka kunjungi.

b. Event and Activities (Acara dan Aktivitas)

Indikator ini memperoleh total skor rata-rata sebesar 3,08 sehingga masuk pada kategori cukup. Berdasarkan skor itu dapat dipahami bahwa para responden dapat dikatakan yang membuat mereka berwisata ke Desa Wisata Trunyan adalah adanya aktivitas di luar ruangan seperti menikmati udara segar pegunungan dan keindahan bentang alam Kintamani. Adapula yang mengatakan tidak ada aktivitas yang menarik untuk dilakukan disana selain melihat-lihat saja serta tidak ada yang mengetahui jadwal festival maupun upacara disana sehingga para responden merasa sedikit kecewa karena tidak dapat menyaksikannya.

c. Affordable Price (Harga yang Terjangkau)

Indikator tersebut memperoleh total skor rata-rata sebesar 2,82 sehingga masuk pada kategori cukup. Sebagian besar responden berpendapat bahwa harga menuju desa wisata ini cukup terjangkau, namun adapula yang berkomentar kurang terjangkau, serta adanya keluhan tentang jarak akomodasi tempat mereka tinggal dengan desa wisata tersebut sangat jauh, seperti yang diketahui bersama bahwa layanan akomodasi berpusat di Bali Selatan, seperti Nusa Dua, Jimbaran, Kuta, Legian, Seminyak, Canggu, Sanur dan yang terdekat dengan desa wisata ini adalah Ubud.

d. Travel Arrangement (Pengaturan Perjalanan)

Indikator ini memperoleh total skor rata-rata sebesar 3,70 sehingga masuk pada kategori setuju. Skor tersebut adalah cerminan pernyataan beberapa responden pada studi ini bahwa paket wisata yang ditawarkan oleh biro perjalanan wisata sangat membantu mereka berwisata khususnya ke Desa Wisata Trunyan.

Faktor penarik wisatawan mancanegara berwisata ke Desa Wisata Trunyan mendapat total skor rata-rata sebesar 3,33 yang masuk dalam kategori cukup yang diperoleh melalui hasil kalkulasi seluruh indikator diatas.

\section{Persepsi Wisatawan}

Persepsi wisatawan mancanegara yang berwisata ke Desa Wisata Trunyan dapat dilihat dibawah ini.

\section{Attraction (Atraksi Wisata)}

Sub variabel ini diklasifikasikan menjadi beberapa indikator, antara lain :

a. Keindahan Alam 
Indikator keindahan alam Desa Wisata Trunyan memperoleh total skor rata-rata 3,68 yang dikategorikan sebagai setuju. Sebagian besar para responden mengemukakan pendapat bahwa bentang alam di sekeliling Desa Wisata Trunyan sangatlah memanjakan indra penglihatan, terbalik dengan atraksi utamanya yaitu kuburan dan desa wisatanya yang belum terjaga dengan baik dan ditemukan cukup banyak sampah sisa makanan dan plastik berserakan diman-mana yang membuat keindahan dan kenyamanan responden berkurang.

b. Iklim dan Cuaca

Indikator ini memperoleh total skor rata-rata 4,48 yang dikategorikan sebagai sangat setuju. Melepaskan diri dari kehidupan perkotaan, kemacetan, kualitas udara yang kurang baik bagi kesehatan, maupun kebisingan yang membuat stres membuat para responden berwisata ke destinasi wisata yang mampu menghilangkan berbagai permasalahan di atas seperti Kintamani khususnya Desa Wisata Trunyan untuk menyegarkan kembali pikiran dan tubuh.

c. Kebudayaan

Indikator ini mendapat total skor ratarata 3,95 sehingga masuk dalam kategori setuju. Sebagian besar para responden menyatakan bahwa kebudayaan yang unik, khas, dan berbeda dengan yang lain inilah yang membuat mereka tidak ragu untuk berwisata ke desa wisata ini.

d. Sejarah

Indikator ini memperoleh total skor rata-rata 3,39 yang dikategorikan sebagai cukup. Berdasarkan observasi terhadap bangunan bersejarah maupun benda cagar budaya di desa wisata ini terlihat alami, namun kebersihannya kurang mendapat perhatian dan banyak ditemukan sisa-sisa sesajen, puntung rokok maupun sampah plastik yang berserakan disekitar area itu. Sehingga tidak dapat dipungkiri bahwa indikator ini mendapat persepsi yang cukup dari para responden.

Persepsi wisatawan mancanegara terhadap atraksi wisata di Desa Wisata
Trunyan memperoleh total skor rata-rata 3,87 dikategorikan sebagai setuju yang didapatkan melalui hasil kalkulasi total skor rata-rata keempat indikator diatas. Diantara keempat indikator itu terdapat beberapa pernyataan yang mendapat tanggapan yang cukup dari 100 orang responden, yaitu kondisi kuburan serta benda cagar budaya Desa Wisata Trunyan yang kurang terawat.

\section{Facility (Fasilitas)}

Sub variabel ini terdiri dari beberapa indikator penilaian, yaitu :

a. Warung Tradisional

Indikator tersebut memperoleh total skor rata-rata 2,73 yang diklasifikasikan sebagai cukup. Dapat diketahui bahwa responden studi ini kurang puas dengan barang/dagangan yang ditawarkan oleh beberapa warung tradisional di dermaga penyeberangan menuju Desa Wisata Trunyan dan harga beberapa makanan dan minuman tertentu cukup mahal jika dibandingkan dengan harga jual di sebuah mini market.

b. Area Parkir

Indikator ini memperoleh total skor ratarata sebesar 4,30 yang dikategorikan sebagai sangat setuju. Area parkir di dermaga penyeberangan menuju Desa Wisata Trunyan dimana para responden memarkirkan kendaraannya termasuk luas, aman karena adanya juru parkir dan masyarakat lokal yang berlalulalang di area parkir tersebut. Hingga saat ini tidak/belum ditemukan adanya kasus kehilangan maupun perusakan kendaraan bermotor.

c. Toilet

Indikator ini memperoleh total skor ratarata 2,45 sehingga masuk kategori tidak setuju. Toilet yang tersedia di dermaga penyeberangan menuju Desa Wisata Trunyan belum memenuhi standar bagi responden, seperti kebersihannya kurang terjaga, terdapat toilet yang tidak bisa difungsikan dengan semestinya, serta tidak adanya sarana pelengkap seperti tisu maupun tempat untuk mencuci tangan beserta sabunnya.

Persepsi para responden terhadap fasilitas yang tersedia di Desa Wisata Trunyan memperoleh total skor rata-rata 
sebesar 3,16 dikategorikan sebagai cukup yang diperoleh dari hasil kalkulasi ketiga indikator diatas. Ketersediaan fasilitas yang mumpuni belum bisa ditemukan di desa wisata ini yang tercermin pada skor beberapa indikator di atas, meliputi indikator warung tradisional dan toilet.

3. Infrastructure (Infrastruktur)

Berikut ini merupakan dua indikator sub variabel infrastruktur.

a. Jaringan Komunikasi

Indikator ini memperoleh total skor rata-rata sebesar 2,85 yang dikategorikan sebagai cukup. Hal tersebut bisa terjadi karena tidak adanya jaringan komunikasi yang dapat dibangun disana, mengingat jalur darat menuju Desa Wisata Trunyan terjal dan sulit dilalui kendaraan besar, sehingga jaringan komunikasi dibangun cukup jauh dari desa wisata ini. Hanya beberapa kartu ponsel tertentu saja yang memiliki jaringan komunikasi yang baik di sekitar Desa Wisata Trunyan.

b. Jalan

Indikator ini mendapat total skor ratarata 4,32 yang dikategorikan sebagai sangat setuju. Berdasarkan skor tersebut dapat dipahami bahwa kondisi jalan maupun papan petunjuk jalan menuju dermaga penyeberangan ke desa wisata ini mudah dilalui kendaraan bermotor karena dewasa ini semua truk galian $\mathrm{C}$ yang mengangkut pasir maupun bebatuan sudah dialihkan jalurnya menuju jalan Culali, sehingga jalan tersebut dalam kondisi yang baik dan aman untuk dilalui oleh semua orang bahkan orang yang baru pertama kali melalui jalan tersebut.

Persepsi responden terhadap infrastruktur yang ada di Desa Wisata Trunyan mendapat total skor rata-rata 3,58 yang diklasifikasikan sebagai setuju yang diperoleh dari hasil kalkulasi kedua indikator tersebut, walaupun salah satu diantaranya memperoleh persepsi cukup dari para responden.

\section{Transportation (Transportasi)}

Layanan transportasi lokal menuju Desa Wisata Trunyan mendapat total skor ratarata 3,82 yang dikategorikan sebagai setuju. Berdasarkan hasil observasi dan komentar responden, penulis mendapat informasi bahwa perahu dan jaket pelampung tersebut aman dan nyaman digunakan untuk menyeberangi danau Batur, namun layanan ini sempat ditutup sementara waktu karena kondisi cuaca yang kurang bersahabat dan membuat ombak danau Batur cukup tinggi ditakutkan akan mengakibatkan perahu tersebut kandas.

\section{Hospitality (Keramahan)}

Adapun dua indikator penilaian pada sub variabel ini adalah sebagai berikut.

a. Pemandu Wisata Lokal

Indikator ini mendapat total skor ratarata 3,92 sehingga masuk kategori setuju. Berdasarkan observasi serta komentar beberapa responden, layanan pemandu wisata lokal yang tersedia disana bisa dikatakan dapat memberikan pelayanan prima yang sesuai dengan ekspektasi para responden walaupun ada beberapa dari mereka yang masih terkendala dengan bahasa maupun kemampuan lainnya.

b. Masyarakat Lokal

Indikator masyarakat lokal mendapat total skor rata-rata 3,25 dikategorikan sebagai cukup. Masyarakat Bali adalah orang yang sangat sopan, ramah serta murah senyum begitu pula masyarakat lokal di Desa Wisata Trunyan. Walaupun ada dari mereka yang menjajakan barang dagangannya dengan sedikit agresif dan memaksa, adapula orang yang telah lanjut usia mengemis kepada wisatawan. Tapi para responden menyikapinya dengan baik seperti membeli barang dagangan tersebut serta adapula yang memberikan uang atau makanan kepada masyarakat lokal karena merasa iba kepada mereka.

Persepsi 100 orang responden terhadap indikator keramahan di Desa Wisata Trunyan mendapat total skor rata-rata sebesar 3,58 yang masuk ke dalam kategori setuju yang diperoleh dari hasil kalkulasi semua indikator diatas. Namun sangat disayangkan 
dengan indikator masyarakat lokal yang memperoleh penilaian yang kurang baik, sehingga perlu adanya kesadaran dari masyarakat setempat untuk membenahi sikap dan sifat yang menyebabkan para wisatawan merasa kurang nyaman untuk berwisata ke desa wisata tersebut.

Berdasarkan kelima sub variabel beserta seluruh indikator yang digunakan sebagai media untuk mengidentifikasi persepsi 100 wisatawan mancanegara yang berwisata ke Desa Wisata Trunyan diperoleh total skor rata-rata sebesar 3,60 yang berarti bahwa seluruh responden memiliki persepsi yang baik/setuju terhadap atraksi wisata, fasilitas, infrastruktur, transportasi serta keramahan yang ada di Desa Wisata Trunyan. Akan tetapi masih banyak pekerjaan rumah yang perlu ditindaklanjuti dan diselesaikan oleh masyarakat lokal dan pemerintah terkait yang berkecimpung dalam pariwisata, seperti bagaimana caranya meminimalisir ataupun membenahi beberapa persepsi negatif para responden di atas, seperti permasalahan pemeliharaan kebersihan serta keramahan masyarakat lokal. Disamping itu, masyarakat setempat beserta pemerintah terkait perlu memaksimalkan apa yang menjadi kekuatan pariwisata Desa Wisata Trunyan, seperti keindahan bentang alam sekitar desa wisata dan membuat sebuah atraksi wisata baru dan mampu menarik kunjungan wisatawan yang lebih banyak lagi di masa yang akan datang sesuai dengan potensi di sekitar desa wisata ini.

\section{SIMPULAN DAN SARAN Simpulan}

Mayoritas wisatawan mancanegara yang berwisata ke Desa Wisata Trunyan adalah wisatawan yang berkewarganegaraan Amerika Serikat sebesar 33\%, wisatawan berusia 15-30 tahun sebesar $40 \%$, wisatawan laki-laki sebesar 55\%, wisatawan yang berkerja sebagai karyawan sebesar 29\%, wisatawan yang berpendidikan master sebesar 39\%. Sebanyak $69 \%$ wisatawan mancanegara menjawab tujuan perjalanannya ke Desa Wisata Trunyan adalah berwisata/rekreasi, $65 \%$ wisatawan menjawab pengorganisasian perjalanannya diatur oleh biro perjalanan wisata, $100 \%$ wisatawan merupakan first timer, $49 \%$ wisatawan mendapat informasi tentang desa wisata ini melalui biro perjalanan wisata, $54 \%$ wisatawan mengeluarkan dana sekitar \$39$\$ 53$, dan $85 \%$ wisatawan yang berwisata ke Desa Wisata Trunyan ditemani oleh teman/keluarga.

Motivasi dapat diklasifikasikan menjadi dua faktor yaitu 1) Faktor pendorong yang terdiri dari lima indikator, yaitu a) Novelty and Knowledge Seeking yang memperoleh total skor rata-rata sebesar 4,10 (setuju), b) Rest and Relaxation yang memperoleh total skor ratarata sebesar 4,02 (setuju), c) Fulfilling Dream yang memperoleh total skor rata-rata sebesar 3,77 (setuju), d) Adventure and Exploration yang memperoleh total skor rata-rata sebesar 4,01 (setuju), dan e) Prestige yang memperoleh total skor rata-rata sebesar 3,98 (setuju). Berdasarkan kelima indikator tersebut, faktor dasar yang mendorong wisatawan mancanegara berwisata ke Desa Wisata Trunyan mendapat total skor rata-rata sebesar 3,98 yang dikategorikan sebagai pernyataan setuju. 2) Sedangkan faktor penarik terdiri atas empat indikator, antara lain a) Safety, Cleanliness, and Variety Attraction yang mendapat total skor rata-rata sebanyak 3,71 (setuju), b) Event and Activities yang mendapat total skor rata-rata sebanyak 3,08 (cukup), c) Affordable Price yang mendapat total skor rata-rata sebanyak 2,82 (cukup), dan d) Travel Arrangement yang mendapat total skor rata-rata sebanyak 3,70 (setuju). Berdasarkan keempat indikator tersebut, faktor dasar yang menarik wisatawan mancanegara berwisata ke Desa Wisata Trunyan memperoleh total skor rata-rata sebesar 3,33 sehingga masuk dalam kategori pernyataan cukup.

Wisatawan mancanegara yang berwisata ke Desa Wisata Trunyan memiliki persepsi baik/setuju terhadap desa wisata tersebut yang mendapat total skor rata-rata sebesar 3,60. Skor tersebut diperoleh melalui lima sub variabel yang terdiri atas 1) Attraction memiliki beberapa indikator, yaitu a) Keindahan Alam memperoleh total skor ratarata sebesar 3,68 (setuju), b) Iklim dan Cuaca memperoleh total skor rata-rata sebesar 4,48 (sangat setuju), c) Kebudayaan memperoleh 
total skor rata-rata sebesar 3,95 (setuju), dan d) Sejarah memperoleh total skor rata-rata sebesar 3,39 (cukup). Berdasarkan keempat indikator tersebut, attraction memperoleh total skor rata-rata sebesar 3,87 yang dikategorikan sebagai pernyataan setuju. 2) Facility memiliki beberapa indikator, yaitu a) Warung Tradisional memperoleh total skor rata-rata sebesar 2,73 (cukup), b) Area Parkir memperoleh total skor rata-rata sebesar 4,30 (sangat setuju), dan c) Toilet memperoleh total skor rata-rata sebesar 2,45 (tidak setuju). Berdasarkan ketiga indikator tersebut, facility memperoleh total skor rata-rata sebesar 3,16 sehingga masuk dalam kategori pernyataan cukup. 3) Infrastructure memiliki beberapa indikator, antara lain a) Jaringan Komunikasi memperoleh total skor rata-rata sebesar 2,85 (cukup), dan b) Jalan memperoleh total skor rata-rata sebesar 4,32 (sangat setuju). Berdasarkan kedua indikator tersebut, infrastructure memperoleh total skor rata-rata sebesar 3,58 sehingga masuk dalam kategori setuju. 4) Transportation memiliki sebuah indikator, yakni a) Layanan Transportasi Lokal memperoleh total skor rata-rata 3,82 (setuju). 5) Hospitality memiliki beberapa indikator, antara lain a) Pemandu Wisata Lokal memperoleh total skor rata-rata sebesar 3,92 (setuju), dan b) Masyarakat Lokal memperoleh total skor rata-rata 3,25 (cukup). Berdasarkan kedua indikator tersebut, hospitality mendapat total skor rata-rata sebesar 3,58 sehingga masuk dalam kategori setuju.

\section{Saran}

Masyarakat lokal perlu memberikan perhatian khusus terhadap kebersihan atraksi utama desa wisata ini yakni kuburan serta fasilitas pendukungnya yakni toilet khususnya yang tersedia di dermaga penyeberangan menuju desa wisata dengan membersihkannya secara berkala maupun menyediakan tempat sampah di beberapa titik tertentu dan papan himbauan untuk membuang sampah pada tempatnya. Selain itu, perlu adanya penambahan beberapa fasilitas pendukung lain di dalam toilet tersebut seperti tisu dan juga tempat cuci tangan serta sabun yang dapat dipakai dengan semestinya. Disamping menata fisik, perlu adanya kesadaran pada diri masyarakat lokal untuk merubah sikap yang merugikan diri mereka sendiri serta membuat wisatawan merasa kurang nyaman.
Pada momen upacara keagamaan berlangsung di Desa Wisata Trunyan yang biasanya jatuh pada bulan Oktober, maka pemerintah terkait perlu melakukan promosi pariwisata dari jauh hari serta melakukan kerja sama dengan beberapa biro perjalan wisata yang ada di Bali. Tindakan ini cukup tepat untuk dilakukan oleh pemerintah terkait guna meningkatkan kunjungan wisatawan di masa yang akan datang ke Desa Wisata Trunyan.

Selain kedua saran di atas, masyarakat lokal beserta pemerintah terkait perlu melakukan sinergitas dalam menangani berbagai permasalahan pariwisata yang melanda Desa Wisata Trunyan melalui beberapa program seperti melaksanakan sosialisasi, pelatihan maupun study banding menuju daerah-daerah yang dirasa lebih baik. Selain memberdayakan sumber daya manusianya, masyarakat lokal beserta pemerintah terkait harus bersinergi dalam memasarkan pariwisata Desa Wisata Trunyan kepada dunia, misalnya melalui media sosial yang sangat pesat perkembangannya. Tetapi program-program ini takkan bisa diimplementasikan dan berhasil apabila kedua elemen utama pariwisata Desa Wisata Trunyan yaitu masyarakat lokal beserta pemerintah terkait tidak bersinergi dengan baik dan program-program ini tidak dilaksanakan secara berkesinambungan.

Kepada pihak yang ingin melakukan penelitian mengenai karakteristik, motivasi, dan persepsi wisatawan khususnya yang berwisata ke Desa Wisata Trunyan pada masa yang akan datang. Adapun saran yang diberikan adalah hendaknya peneliti selanjutnya melakukan penelitian dengan teori, variabel maupun indikator yang berbeda serta meneliti wisatawan nusantara, sehingga karakteristik, motivasi, maupun persepsi wisatawan baik wisatawan mancanegara maupun nusantara yang berwisata ke Desa Wisata Trunyan dapat teridentifikasi, serta dapat dijadikan acuan untuk studi komparasi karakteristik, motivasi, dan persepsi antara wisatawan mancanegara maupun nusantara. 


\section{Kepustakaan}

Anonim. 1969. Tujuan Pengembangan Pariwisata di Indonesia. Instruksi Presiden Republik Indonesia Nomor 9 Tahun 1969 BAB II Pasal 3.

2018. Analisa Pasar Pariwisata Kabupaten Bangli. Bangli : Dinas Pariwisata dan Kebudayaan Kabupaten Bangli.

. 2018. Data Jumlah Kunjungan Wisatawan Mancanegara ke Indonesia pada Januari-Agustus 2018. Indonesia : Badan Pusat Statistik Indonesia.

2019. Data Jumlah Kunjungan Wisatawan Mancanegara ke Desa Wisata Trunyan Tahun 2014-2018. Bangli : Dinas Pariwisata dan Kebudayaan Kabupaten Bangli.

. 2019. Data Jumlah Kunjungan Wisatawan Mancanegara ke Bali Tahun 2014-2018. Bali : Badan Pusat Statistik Provinsi Bali.

Bennet, Seaton. 1996. Marketing Tourism Products. Oxford : Alden Press.

Spillane, James J. 1994. Pariwisata Indonesia : Siasat Ekonomi dan Rekayasa Kebudayaan. Yogyakarta : Kanisius.

Yuan, S. dan McDonald, C. 1990. Motivational Determinates of International Pleasure Time. Travel Research Journal. 